\title{
Evaluation of On-Farm Drip Irrigation Systems Design in Bengaluru Rural District, Karnataka - A Case Study
}

\author{
H.P. Ajay Kumar* and H.G. Ashoka
}

Department of Agricultural Engineering, UAS, GKVK, Bengaluru - 560065, Karnataka, India

*Corresponding author

\section{A B S T R A C T}

\begin{tabular}{|c|}
\hline Keywords \\
\hline $\begin{array}{l}\text { Frictional head loss, } \\
\text { Horsepower, } \\
\text { Pipelines, Pressure } \\
\text { drop }\end{array}$ \\
\hline Article Info \\
\hline $\begin{array}{l}\text { Accepted: } \\
16 \text { August } 2018 \\
\text { Available Online: } \\
\text { 10 September } 2018\end{array}$ \\
\hline
\end{tabular}

\section{Keywords}

Horsepower,

Pipelines, Pressure

Article Info

Accepted:

Available Online:

10 September 2018
The study was undertaken in Bengaluru rural district during 2017-18 to evaluate the design of the inline drip irrigation systems in farmers' fields. There are 15 farmers' fields selected for the evaluation. Detailed information of farmers' was collected from Karnataka state Department of Horticulture. The objective of this study is to evaluate the design of drip irrigation systems. The design of the installed irrigation system is evaluated for the suitability of pump, head loss, horse power, discharge and pressure at $1.00 \mathrm{Kg} / \mathrm{cm}^{2}$ operating pressure. To estimate the friction head loss of drip systems, the DarcyWeishbach equation for smooth pipes in drip irrigation can be combined with the Blassius equation is used. The informations on existing HP in the fields were collected from individual farmers. Finally, the calculated horsepower and the existing horsepower are compared to know the suitability of power to operate the irrigation system. The results of design evaluation showed that 10 fields having a good operating system and the 5 fields are not capable to operate the system, which results in poor performance of the system.

\section{Introduction}

Water is one of the important and primary inputs in agricultural production. Agriculture consumes about 70 - 80 per cent of available water in the world (Duhrkoop et al., 2009). However, the scarcity of water availability has necessitated for improvement in efficient irrigation methods in agriculture.

The increase in demand for water in different areas such as industrial, agricultural and domestic purposes cause the needs for improving the new water use efficiency techniques for cultivation of crops. As the conventional methods of irrigation have less water use efficiency, it is important to adopt alternative water application methods such as micro-irrigation techniques which include sprinkler and drip irrigation methods.

The application efficiency of the conventional methods is very low and it is less than 50 percent. The excess application of water creates a problem of water loss by surface runoff and also results in deep percolation losses.

The improved water application method such as the drip irrigation allows précised uniform distribution of water and also decreases nutrient leaching (Phene et al., 1994). 
Properly designed and installed Drip irrigation system results in reduced water loss and cost of the system. Also the best-designed drip irrigation system needs proper maintenance and periodic evaluation (Dasberg and Bresler, 1985). The evaluation procedure consists of periodic measurements of pressure losses through the filters and measurement of discharge rate and pressure at several locations.

\section{Materials and Methods}

The present study was carried out during 2017-18 in the farmer's field of different villages of Nelamangala, Devanahalli, Doddaballapura and Hosakote taluks of Bengaluru rural district. The detail of farmers is collected from the State Government, Department of Horticulture pertaining to different taluks of Bengaluru rural district. The information of different farmers of Bengaluru rural districts who have installed drip irrigation system is collected from Karnataka state Department of Horticulture. The questionnaire for interview and evaluation was prepared to get the details of the farmer's field. The schedule includes the general information of farmers, water source, pump, drip irrigation system, dripper discharge and lateral pressure.

Proper design is very important for successful operation of the drip irrigation system. The design of the drip irrigation system is developed by considering certain factors including agro-climatic conditions, crop physiology, soil characteristics, water source and other engineering factors. Evaluation of such design parameters is cross-checked for the different drip installations for its suitability of pump, head loss, horsepower, discharge and pressure.

The observations of emitter discharge and submain discharge were calculated to find the required HP of the system. To calculate the required HP, the frictional head loss in the laterals, submains and mains has to be observed. To estimate the friction head loss of drip irrigation laterals, the Darcy-Weishbach equation for smooth pipes in drip irrigation is combined with the Blassius equation as follows.

$\mathrm{H}_{\mathrm{fl}}=\mathrm{K} \times \mathrm{L} \times \mathrm{Q}^{1.75} \times \mathrm{D}^{-4.75} \times \mathrm{F}(1)$

Where,

$\mathrm{H}_{\mathrm{fl}}=$ Frictional loss in lateral pipes

$\mathrm{K}=\mathrm{A}$ constant whose value is $7.89 * 10^{5}$ for SI unit of water at $20^{\circ} \mathrm{C}$

$\mathrm{L}=$ length of the pipe in, $\mathrm{m}$

$\mathrm{Q}=$ rate of flow in pipe, $1 / \mathrm{sec}$

$\mathrm{D}=$ diameter of the pipe, $\mathrm{mm}$

$\mathrm{F}=$ factor of the multiple outletsflows.

The value of $\mathrm{F}$ is 0.376 and 0.389 for laterals and sub-main respectively. The value of $F$ is 1 for mainline as the main is having only a few outlets for sub main connections. Christiansen's formula (1942) is used to calculate the $\mathrm{F}$ values.

The system design is divided in sequence as main, submain and lateral. There could be one or few submains and each submain has got few laterals. The drippers are positioned on the laterals to irrigate the fields. The rate of discharge of each emitter and the total number of emitters of all the drippers on the laterals must have sufficient discharge capacity to accommodate flow from the main and submain. For the number of submain and lateral, there should be enough pressure for the flow to meet the expected discharge from individual drippers. Any mismatching of a 
number of submain, lateral and emitter capacity will results in poor discharge or damage to the system. Therefore effective functioning of the drip irrigation system mainly depends on the designed discharge

The equation (1) can also be used to calculate the head loss due to friction in submain and mains. This head loss may vary from laterals due to varied length, diameter and discharge as suggested by Giuseppe et al., (2005). Generally, the discharge of both the main and submain are uniform and equal to the value of the pump discharge.

The main and submain friction head loss is denoted as $\mathrm{H}_{\mathrm{fm}}$ and $\mathrm{H}_{\mathrm{fs}}$ respectively. By using the digital Vernier callipers and measuring tape, the diameter and length of the laterals, submain and main are measured in the farmer's field.

In all the fields, the frictional loss due to filters bends, etc. is taken as $1.5 \mathrm{~m}$ for the complete drip irrigation system. The pressure drop due to filters is specified as 0.3 to $0.5 \mathrm{~m}$. (Hema Krishna, 2009). Then the total head requirement of the system is calculated by using Darcy-Weishbach equation as

$\mathrm{H}_{\text {sys }}=$ Head require for operation + friction

loss + filter loss + bend losses

$\mathrm{H}_{\mathrm{sys}}=\mathrm{H}_{\mathrm{o}+} \mathrm{H}_{\mathrm{fl}+}+\mathrm{H}_{\mathrm{fs}}+\mathrm{H}_{\mathrm{fm}}+\mathrm{H}(2)$

Where,

$\mathrm{H}_{\text {sys }}=$ Total head requirement of the system, $\mathrm{m}$

$\mathrm{H}_{\mathrm{o}}=$ Head required to operate the System, $\mathrm{m}$

$\mathrm{H}_{\mathrm{fl}}=$ Total head loss in the lateral, $\mathrm{m}$

$\mathrm{H}_{\mathrm{fs}}=$ Total head loss in the Sub-Main, $\mathrm{m}$

$\mathrm{H}_{\mathrm{fm}}=$ Total head loss in the Main, $\mathrm{m}$
$\mathrm{H}=$ Head loss due to Bends and Filters, $\mathrm{m}$

The friction losses in the suction pipes are taken as $6 \mathrm{~m}$ per $100 \mathrm{~m}$ pipe as a proposal by Al-Ghobari (2005)

Therefore the head required for the pump is

$\mathrm{H}_{\text {Total }}=\mathrm{H}_{\mathrm{sys}}+\mathrm{H}_{\mathrm{s}+} \mathrm{H}_{\mathrm{fs}+} \mathrm{H}_{\mathrm{d}+} \mathrm{H}_{\mathrm{v}}+\mathrm{H}_{\mathrm{fd}}$ (3)

Where,

(Darcy-Weishbach equation)

$\mathrm{H}_{\text {sys }}=$ Total head requirement of the system, $\mathrm{m}$

$\mathrm{H}_{\mathrm{s}}=$ Total suction Head, $\mathrm{m}$

$\mathrm{H}_{\mathrm{fs}}=$ Friction loss in Suction Pipe, $\mathrm{m}$

$\mathrm{H}_{\mathrm{d}}=$ Delivery head, $\mathrm{m}$

$\mathrm{H}_{\mathrm{v}}=$ Velocity head, $\mathrm{m}$

Then, the size of the pumping unit can be calculated using the equation

$\mathrm{H} . \mathrm{P}=\frac{\mathrm{Q} \times \mathrm{H}}{75 \times \eta \mathrm{p} \times \eta \mathrm{m}}$

Where,

H.P $=$ Horsepower of the pump

$\mathrm{Q}=$ Capacity of the drip irrigation system, $1 / \mathrm{sec}$

$\mathrm{H}=$ Total head requirement of the pump, $\mathrm{m}$

$\eta_{p}=$ Efficiency of the pump, fraction

$\eta_{\mathrm{m}}=$ Efficiency of the motor, fraction

The efficiency of the pump and motor is assumed as 90 per cent as all the pumps used are centrifugal monoblock directly coupled to the motor drive. 


\section{Results and Discussion}

There are 15 drip irrigating farm fields of different farmers who are considered for the studies. The drip irrigation system of different farmer's field area ranges from 0.65 to 3 acre. The power required to operate the drip irrigation system is estimated by considering the various losses in the system. The estimated horsepower and the existing horsepower are compared to know the suitability of power to operate the irrigation system. The irrigation system operation is measured and compared with the estimated power requirement. Also the head losses in the different section of the drip irrigation system for the selected field is worked out.
The drip irrigation system comprises of main pipeline, sub-pipeline and laterals. The diameter of the main pipeline used in the design of drip irrigation system is observed to be $63 \mathrm{~mm}$ size. The submain pipeline diameter is observed to be in between $40 \mathrm{~mm}$ and 50 $\mathrm{mm}$. Similarly, the laterals used in all the fields are with $16 \mathrm{~mm}$ diameter with an emitter capacity of $4 \mathrm{lph}$. Also the drippers are spaced at $40 \mathrm{~cm}$ on laterals.

The power requirement of the drip irrigation system is estimated for 15 farmer's field. Among the different fields, there are 10 farmer's field having a water source as bore well and the remaining 5 farmers having a water source as a farm pond (Table 1).

Table.1 Diameter and lengths of laterals, sub-mains and mains of the drip irrigation systems

\begin{tabular}{|c|c|c|c|c|c|c|c|c|c|c|}
\hline \multirow{2}{*}{$\begin{array}{l}\text { Sl. } \\
\text { No. }\end{array}$} & \multirow{2}{*}{$\begin{array}{l}\text { Field } \\
\text { No. }\end{array}$} & \multirow{2}{*}{$\begin{array}{c}\text { Area } \\
\text { (acre) }\end{array}$} & \multirow{2}{*}{$\begin{array}{l}\text { Depth of } \\
\text { water } \\
\text { source } \\
\text { (m) }\end{array}$} & \multirow{2}{*}{$\begin{array}{c}\text { Emitter } \\
\text { Capacity } \\
\text { Q (lph) }\end{array}$} & \multicolumn{3}{|c|}{ Diameter (mm) } & \multicolumn{3}{|c|}{ Length (m) } \\
\hline & & & & & Main & $\begin{array}{c}\text { Sub } \\
\text { main }\end{array}$ & Lateral & Main & $\begin{array}{c}\text { Sub } \\
\text { main }\end{array}$ & Lateral \\
\hline 1 & F1 & 3.03 & 92.0 & 4 & 63 & 50 & 16 & 215 & 298 & 2440 \\
\hline 2 & $\mathrm{~F} 2$ & 1.15 & 275 & 4 & 63 & 50 & 16 & 452 & 100 & 1530 \\
\hline 3 & F3 & 2.55 & 244 & 4 & 63 & 40 & 16 & 569 & 227 & 1440 \\
\hline 4 & $\mathrm{~F} 4$ & 1.05 & 77.0 & 4 & 63 & 40 & 16 & 365 & 70 & 1500 \\
\hline 5 & F5 & 2.07 & 274 & 4 & 63 & 50 & 16 & 2200 & 240 & 1056 \\
\hline 6 & F6 & 2.46 & 77.0 & 4 & 63 & 40 & 16 & 240 & 246 & 2120 \\
\hline 7 & F7 & 0.65 & 305 & 4 & 63 & 40 & 16 & 69 & 46 & 633 \\
\hline 8 & F8 & 1.23 & 198 & 4 & 63 & 50 & 16 & 385 & 164 & 1290 \\
\hline 9 & F9 & 2.00 & 168 & 4 & 63 & 50 & 16 & 192 & 200 & 1640 \\
\hline 10 & F10 & 3.28 & 183 & 4 & 63 & 50 & 16 & 165 & 150 & 1485 \\
\hline 11 & F11 & 1.20 & 3.00 & 4 & 63 & 50 & 16 & 95 & 92 & 1560 \\
\hline 12 & $\mathrm{~F} 12$ & 1.75 & 10.0 & 4 & 63 & 40 & 16 & 100 & 200 & 1428 \\
\hline 13 & F13 & 2.05 & 3.35 & 4 & 63 & 40 & 16 & 152 & 300 & 836 \\
\hline 14 & F14 & 1.25 & 3.00 & 4 & 63 & 40 & 16 & 154 & 164 & 810 \\
\hline 15 & F15 & 1.08 & 3.00 & 4 & 63 & 50 & 16 & 138 & 144 & 720 \\
\hline
\end{tabular}


Int.J.Curr.Microbiol.App.Sci (2018) 7(9): 2320-2325

Table.2 Power requirement of the drip irrigation system for bore well as water source

\begin{tabular}{|c|c|c|c|c|c|c|c|c|c|c|}
\hline \multirow{2}{*}{$\begin{array}{l}\text { Sl. } \\
\text { No. }\end{array}$} & \multirow{2}{*}{$\begin{array}{l}\text { Field } \\
\text { No. }\end{array}$} & \multirow{2}{*}{$\begin{array}{l}\text { Area } \\
\text { (acre) }\end{array}$} & \multirow{2}{*}{$\begin{array}{c}\text { Existing HP } \\
\text { / Stages }\end{array}$} & \multicolumn{6}{|c|}{ Frictional head (m) } & \multirow{2}{*}{$\begin{array}{c}\text { Calculated } \\
\text { HP }\end{array}$} \\
\hline & & & & Hfm & Hfs & Hfl & Hsys $_{\text {sys }}$ & Hsuc & Htotal & \\
\hline 1 & $\mathrm{~F} 1$ & 3.03 & $10 / 17$ & 2.40 & 2.18 & 16.57 & 18.20 & 92 & 115.78 & 8.60 \\
\hline 2 & $\mathrm{~F} 2$ & 1.15 & $25 / 48$ & 5.76 & 1.62 & 6.27 & 19.51 & 275 & 311.04 & 22.45 \\
\hline 3 & F3 & 2.55 & $22 / 42$ & 7.72 & 3.29 & 10.01 & 23.24 & 244 & 281.93 & 21.79 \\
\hline 4 & $\mathrm{~F} 4$ & 1.05 & $7.5 / 15$ & 4.21 & 1.52 & 13.38 & 17.12 & 77 & 98.76 & 6.40 \\
\hline 5 & F5 & 2.07 & $17.5 / 32$ & 10.7 & 1.51 & 1.48 & 24.24 & 274 & 314.74 & 26.39 \\
\hline 6 & F6 & 2.46 & $7.5 / 14$ & 2.86 & 4.22 & 4.32 & 19.14 & 77 & 100.78 & 5.97 \\
\hline 7 & F7 & 0.65 & $20 / 40$ & 1.46 & 1.6 & 14.07 & 15.92 & 305 & 339.25 & 23.79 \\
\hline 8 & $\mathrm{~F} 8$ & 1.23 & $15 / 26$ & 4.59 & 1.085 & 9.26 & 17.83 & 198 & 227.74 & 16.76 \\
\hline 9 & F9 & 2.00 & $12 / 20$ & 1.99 & 1.33 & 7.93 & 15.45 & 168 & 193.56 & 13.12 \\
\hline 10 & F10 & 3.28 & $15 / 30$ & 1.84 & 0.94 & 7.18 & 14.94 & 183 & 208.96 & 14.57 \\
\hline
\end{tabular}

Table.3 Power requirement of the drip irrigation system for farm pond as water source

\begin{tabular}{|c|l|l|c|c|c|c|c|c|c|c|}
\hline $\begin{array}{c}\text { S1. } \\
\text { No. }\end{array}$ & Field & $\begin{array}{c}\text { Area } \\
\text { No. }\end{array}$ & Existing & \multicolumn{6}{|c|}{ Frictional head (m) } & Calculated \\
\hline $\mathbf{1}$ & F11 & 1.20 & 5 & 2.62 & 2.60 & 18.5 & 17.76 & 3 & 21.01 & 2.70 \\
\hline 2 & F12 & 1.75 & 5 & 2.65 & 15.60 & 16.03 & 49.33 & 10 & 59.98 & 3.93 \\
\hline 3 & F13 & 2.05 & 2 & 1.90 & 2.20 & 5.18 & & 3.35 & 19.96 & 1.93 \\
\hline 4 & F14 & 1.25 & 5 & 3.90 & 7.03 & 13.09 & 23.46 & 3 & 27.27 & 7.21 \\
\hline 5 & F15 & 1.08 & 3 & 1.43 & 0.81 & 12.71 & 26.95 & 3 & 30.14 & 4.71 \\
\hline
\end{tabular}

The results of Table 2 shows that among the 10 farmer fields having a bore well, 6 fields (F1, F2, F3, F4, F6 and F10) having the sufficient pump size to operate the drip irrigation system. Observation of the 2 field (F8 and F9) showed that the calculated pump size is slightly more than existing pump size.

However, with some modifications in the field, the system can be operated efficiently. Observation of the 2 farmer's field (F5 and F7) indicated that the calculated pump size is higher than the existing pump size. Therefore the pump is not sufficient to operate the drip irrigation system effectively. Poorly designed system results in the overall poor performance with low-pressure head, large variation in operating pressure between the lateral inlet and end plug position of the lateral. Therefore the design is inadequate to operate the drip irrigation system.

The results of Table 3 show that there are 5 farmer field having a farm pond as a water source. The 3 different fields (F11, F12 and F13) having the sufficient pump size to operate the drip irrigation system. But in F14 and F15 farmer field, the existing pump size is not sufficient to operate the drip irrigation system.

The study was carried out to evaluate the design of the inline drip irrigation systems in 
the farmers' fields. The design was evaluated in the farmer's field by calculating the different frictional losses in the drip irrigation systems at $1.00 \mathrm{Kg} / \mathrm{cm}^{2}$ operating pressure. The overall results of the study revealed that only 60 per cent of the farmers' fields having good operating systems. Therefore, there is a need to redesign for the best operating system.

\section{References}

Al-Ghobari, 2005. Trickle irrigation application uniformity from simple emitters. Trans. Amer. Soc. Agric. Eng., 16 (6): 1108-1111.

Christiansen, J, E., 1942. Hydraulics of sprinkling systems for irrigation. Trans. Amer. Soc. Agric. Eng., 107: 221-239.

Giuseppe, P., Domenico, P. and Pietro, D., 2005. Simplified procedure to evaluate head losses in drip irrigation laterals. J. Irrig. Drain. Eng., 131: 525-532.

Hema Krishna, 2009. Study of hydraulic parameters of drip irrigation systems in farmers' fields under different crops. M.tech Thesis (Unpub), Acharya N. G. Ranga Agricultural University.
Reddy, K. Y., Tiwari, K. N. and Ravindra, V., 2000. Hydraulic analysis of trickle irrigation for economic design. International Agricultural Engineering Journal, 9 (2): 81-95.

Shete, D. T., 2005. Determining of factors for laterals in micro-irrigation. In: Chaudhary M.L., Chandra P. and Mishra P. (Eds.) Proceeding of International conference on Plasticulture and Precision Farming, held during November 17-21, 2005 at New Delhi. p. 91-97.

Singh, S. K., 1999. Standardization of materials and quality parameters of micro-irrigation systems. Proceedings of the National Seminar on Problems and Prospects of Micro Irrigation - A Critical Appraisal, Bangalore, Nov 1920, 1999. Institution of Engineers (India), p. 107-114.

Yeldirim, G., 2006. Discussion of "Experimental analysis of local pressure losses for micro-irrigation laterals" by Guiseppe, Provenzano and Domenico Pumo. J. Irrig. Drain. Eng., ASAE, 132:189-193.

\section{How to cite this article:}

Ajay Kumar, H.P. and Ashoka, H.G. 2018. Evaluation of On-Farm Drip Irrigation Systems Design in Bengaluru Rural District, Karnataka - A Case Study. Int.J.Curr.Microbiol.App.Sci. 7(09): 2320-2325. doi: https://doi.org/10.20546/ijcmas.2018.709.288 